\title{
ROLE OF COMBINATION CASEIN AND LACTOFERRIN BOVINE'S COLLOSTRUM AS A PULP CAPPING ON MACROPHAGE EXPRESSION IN MALE WISTAR RATS
}

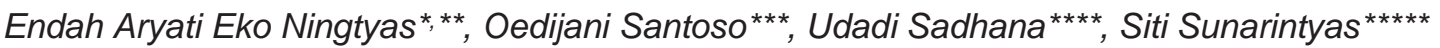

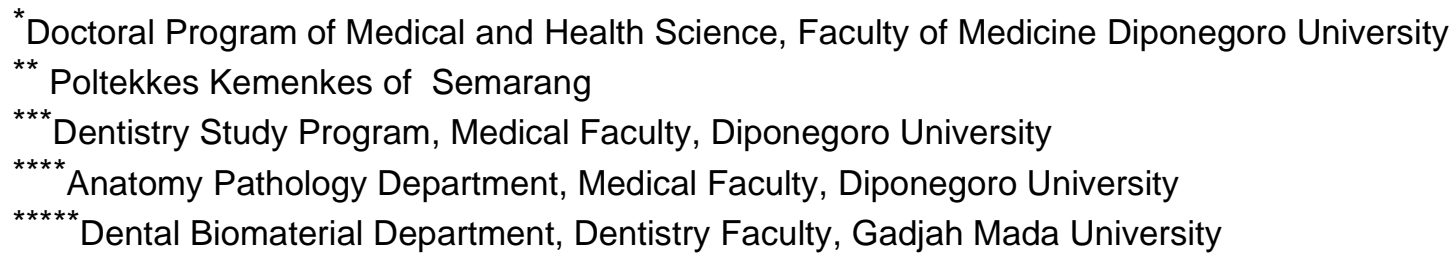

Correspondence: endahaeyatu@gmail.com

\section{Keywords: macrophages, combination of casein and lactoferrin bovine colostrum, capping pulp}

\section{ABSTRACT}

Background: Inflammatory and/or non-inflammatory processes play a role in stimulating pulp repair and the formation of hard tissue, namely reparative dentin. Macrophages play a role in the pathogenesis and chronic inflammatory disorders. The combination casein lactoferrin of bovine colostrum as an immunomodulator has therapeutic potential. This study aims to determine the therapeutic effect and duration of application of the combination of casein lactoferrin of bovine colostrum, on the expression of macrophages as pulp capping.

Method: This study was a true experimental laboratories post test only control group design, consisting of three groups of 60 male wistar rats with 4 observation times, namely day to day 7, 14, 21 and 28 each of 5 mice. The maxillary $1^{\text {st }}$ molars were prepared until the roof of the pulp was exposed. Three groups, namely the combination of casein and lactoferrin bovine colostrum (CKL) and calcium hydroxide (K1) and the untreated group (KO). Each group was filled with glassionomer as a permanent restoration. The tissue was made histological preparations with hematoxylin-eosin staining and the number of macrophages were counted, then analyzed by two way ANOVA and post hoc LSD tests.

Result:

The results showed that the therapeutic effect and duration of application of the combination of casein and lactoferrin bovine colostrum on the expression of macrophages as pulp capping

Conclusion: The combination of casein and lactoferrin of bovine colostrum as capping material can increase the number of macrophages in the healing process of dental pulp.

\section{PENDAHULUAN}

Penyembuhan luka merupakan proses kompleks yang melibatkan sel inflamasi dan faktor pertumbuhan yang saling berpengaruh pada setiap tahap penyembuhan. Proses

Tahap inflamasi didominasi oleh neutrophil yang berlangsung hingga beberapa hari kemudian digantikan oleh makrofag sebagai bagian dari inflamasi akhir, di mana sitokin penyembuhan luka dimulai pada tahap inflamasi dan memerlukan waktu selama beberapa menit hingga jam yang dikenal dengan peradangan akut.

yang dihasilkan oleh sel $\mathrm{T}$ menginduksi inflamasi 1. Inflamasi akhir yang terjadi merupakan awal dari proses penyembuhan. Makrofag terlihat pada 48-72 jam setelah 
cedera dan berperan pada proses fagositosis.

Selanjutnya diikuti oleh fase proliferasi sel dan pembentukan pembuluh darah baru yang dikenal sebagai jaringan granulasi. Proses sintesis, remodeling, dan infiltrasi struktural dari molekul matriks ekstra selular sangat ditentukan pada tahap awal dan lanjut dari penyembuhan luka ${ }^{2}$. Studi terbaru menunjukkan bahwa makrofag dapat dijumpai pada beberapa tahap penyembuhan luka yang berbeda dan berpengaruh secara bervariasi terhadap setiap tahap perbaikan di mana makrofag dapat pula menyebabkan peradangan yang berlebihan. Kondisi jaringan granulasi yang diremodeling oleh sel-sel radang seperti neutrofil dan makrofag dalam jangka waktu cukup lama menyebabkan pembentukan jaringan ikat akan terhambat. Disfungsi makrofag atau jumlah makrofag yang rendah dalam proses perbaikan jaringan menyebabkan penyembuhan luka tidak optimal serta terhambatnya proliferasi fibroblas dan angiogenesis ${ }^{3}$.

Makrofag memiliki dua fungsi utama, yaitu menghancurkan antigen dan melepaskan berbagai enzim serta isi granula ke luar sel bersamaan dengan sitokin seperti Tumor Necrosis Factor (TNF) hingga mampu membunuh organisme patogen. Fungsi kedua yaitu sebagai Antigen Presenting Cell (APC) yang memberikan antigen kepada limfosit ${ }^{4}$. Selain itu makrofag memiliki kemampuan sebagai pengatur tingkat peradangan dan perekrutan neutrofil ${ }^{5}$. Lipopolisakarida (LPS) merupakan komponen utama dari endotoksin akan menginduksi aktivasi makrofag, selanjutnya berpengaruh terhadap peningkatan ekspresi Inducible Nitric Oxide
Synthase (iNOS) sehingga menghasilkan produksi oksida nitrat (NO) yang berlebihan ${ }^{6}$. NO memainkan peran penting dalam respons imun inflamasi dan pertahanan host terhadap berbagai patogen seperti bakteri dan virus 7. Namun, NO dalam jumlah tinggi memiliki sitotoksisitas dan menginduksi kerusakan jaringan yang berhubungan dengan inflamasi akut dan kronis.

Dalam situasi di mana ada kerusakan pada struktur gigi yang menyebabkan terbukanya pulpa gigi, beberapa jenis sel imun berperan dalam melindungi pulpa gigi terhadap benda asing yang berpotensi menyebabkan infeksi ${ }^{8}$. Diketahui bahwa makrofag terdapat dalam pulpa gigi dan peran mereka dalam pembentukan dentin reparatif sampai saai ini belum sepenuhnya dipahami ${ }^{9}$. Makrofag memengaruhi Wnt yang berhubungan dengan diferensiasi sel induk hal ini menunjukkan kemungkinan terdapat interaksi langsung antara makrofag dan sel induk ${ }^{10}$. Memahami proses inflamasi yang terjadi di pulpa gigi sebagai respons terhadap kerusakan dentin dan efek terhadap aktivasi sel induk penting untuk merencanakan terapi yang berpengaruh bagi pembentukan dentin tersier. Proses inflamasi dan atau non inflamasi berperan untuk menghasilkan dentin reparatif tergantung pada induksi terhadap reaksi pulpa yang dipengaruhi oleh bentuk karies dan tingkat keparahan proses inflamasi dan non-inflamasi juga bahan kaping yang yang digunakan.

Kaping pulpa adalah perawatan yang diindikasikan untuk pulpa yang disebabkan adanya faktor trauma atau karena faktor iatrogenik, di mana proses penyembuhan diawali dengan fase inflamasi akut. Selama ini 
standar bahan kaping yang digunakan di Bagian Konservasi adalah kalsium hidroksida $(\mathrm{CaOH})$. $\mathrm{CaOH}$ dapat memicu pertumbuhan dentin tersier karena memiliki $\mathrm{pH}$ tinggi 12,5y yang dapat menyebabkan terjadinya pelepasan ion $\mathrm{OH}$ - dan mengakibatkan peningkatan respon inflamasi ${ }^{11}$. Kalsium hidroksida juga memiliki kerugian yaitu menyebabkan nekrosis permukaan pulpa setelah aplikasi bahan kaping, kelarutan tinggi, pembentukan jembatan dentin yang buruk, dan resistensi mekanik rendah.

Saat ini dikembangkan pemakaian sumber alam yang digunakan sebagai alternatif sebagai obat atau bahan perawatan di bidang kesehatan untuk mengurangi efek samping pemakaian bahan berdasar bahan kimia yang tersedia. Salah satu bahan yang dapat digunakan adalah pemakaian bahan kombinasi kasein dan laktoferin kolostrum susu sapi. Kolostrum susu sapi merupakan salah satu sumber alam yang memiliki kandungan kasein dan laktoferin yang tinggi. Diketahui bahwa fungsi dari masingmasing bahan memiliki fungsi bagi kesehatan yaitu laktoferin adalah glikoprotein pengikat besi multifungsi $\sim 80 \mathrm{kDa}$ dari keluarga transferrin. Laktoferin adalah activator yang poten bagi makrofag ${ }^{11}$. Kasein bersifat imunomodulator yang memengaruhi makrofag. Kasein mengurangi fungsi fagositosis makrofag dan menekan produksi spesies oksigen dan nitrogen reaktif sebagai respons terhadap rangsangan inflamasi. kappa-kasein secara signifikan mengurangi TNF- $\alpha$ dan IL-10 ${ }^{12}$.

Oleh karena itu, penelitian ini dilakukan untuk mengetahui pengaruh penggunaan bahan imunomodulator protein bioaktif berbasis kasein laktoferin kolostrum susu terhadap sel makrofag pada peradangan pulpa gigi untuk memajukan pemahaman kita tentang dampaknya terhadap sel-sel imunitas, yang berpotensi mengarah pada penemuan alternatif baru yang layak sebagai bahan kaping pulpa.

\section{METODE}

Penelitian ini merupakan penelitian eksperimental laboratorium dengan design post test control group design. Penelitian ini menggunakan 60 tikus Wistar jantan umur 12-16 minggu dengan berat 300-350 gram. Hewan coba dibagi menjadi 3 kelompok (masingmasing dengan 20 ekor) yaitu kelompok preparasi dan tanpa bahan perawatan kaping (K0); kelompok bahan kaping dengan kombinasi kasein laktoferin kolostrum susu sapi (CKL); kelompok bahan kaping memakai $\mathrm{CaOH}(\mathrm{K} 1)$. Preparasi dilakukan pada molar pertama rahang atas hewan coba dan kavitas dibuat perforasi di kamar pulpa dengan anestesi lokal. Pengamatan dilakukan pada Hari ke 7, 14, 21, dan 28 di mana masing masing hari pengamatan butuh 5 hewan coba. Sesuai dengan hari pengamatan, kemudian hewan coba diinkubasi selama 7 hari sebelum akhirnya didekapitasi dan pembuatan preparat jaringan sebagai berikut difiksasi selama 4 hari dengan formalin 10\% kemudian didekalsifikasi dengan EDTA $15 \%$ selama 60 hari. Proses selanjutnya deparafinisasi, parafin diblokir, direndam dalam PBS, diteteskan dengan tripsin $0,025 \%$, dicuci dengan PBS $3 x$, diteteskan dengan $\mathrm{H}_{2} \mathrm{O}_{2}$ dicuci dengan PBS 3x, dipotong dengan mikrotom dan pewarnaan HE. Sel-sel inflamasi yaitu makrofag diamati di bawah mikroskop cahaya dengan pembesaran 400x bidang pandang dan data dianalisis menggunakan two way ANOVA kemudian diikuti uji post hoc LSD. 
HASIL

Hasil penelitian menunjukkan bahwa jumlah rata-rata ekspresi sel makrofag tertinggi pada kelompok tanpa perawatan (K0), kemudian kelompok kombinasi kasein laktoferin (CKL) dan terendah pada kelompok kelompok kalsium hidroksida (K1). Penelitian ini menganalisis jumlah ekspresi makrofag pada pulpa perforasi tikus Wistar pada hari ke-7, 14, 21, dan 28 (Tabel 1).

Tabel 1. Rerata dan simpangan baku ekspresi makrofag pada kelompok kombinasi kasein laktoferin, $\mathrm{CaOH}$, dan tanpa perlakuan dalam berbagai lama perlakuan

\begin{tabular}{llll}
\hline Lama perlakuan & \multicolumn{3}{l}{ Jenis Perlakuan } \\
\cline { 2 - 4 } & Kontrol $(\mathrm{K} 0)$ & $\mathrm{CaOH}(\mathrm{K} 1)$ & $\mathrm{CKL}$ \\
\hline 7 hari & $20,00 \pm 3,81$ & $1,00 \pm 1,00$ & $8,00 \pm 2,91$ \\
14 hari & $25,00 \pm 2,92$ & $5,00 \pm 1,00$ & $3,00 \pm 1,22$ \\
21 hari & $18,00 \pm 1,23$ & $10,00 \pm 2,55$ & $13,00 \pm 2,24$ \\
\hline
\end{tabular}

Pada Tabel 1 menunjukkan bahwa ekspresi laktoferin (CKL) dan terendah dalam kelompok tertinggi terlihat jumlah sel makrofag pada hari ke $7,14,21$, dan 28 pada kelompok kontrol (K0) kalsium Hidroksida (K1). Jumlah rata-rata sel ,diikuti oleh kelompok Kombinasi kasein dan makrofag kecenderungan lebih tinggi pada ke21 untuk kelompok CKL dan K0.

Deskripsi jumlah makrofag menurut jenis dan lama perlakuan

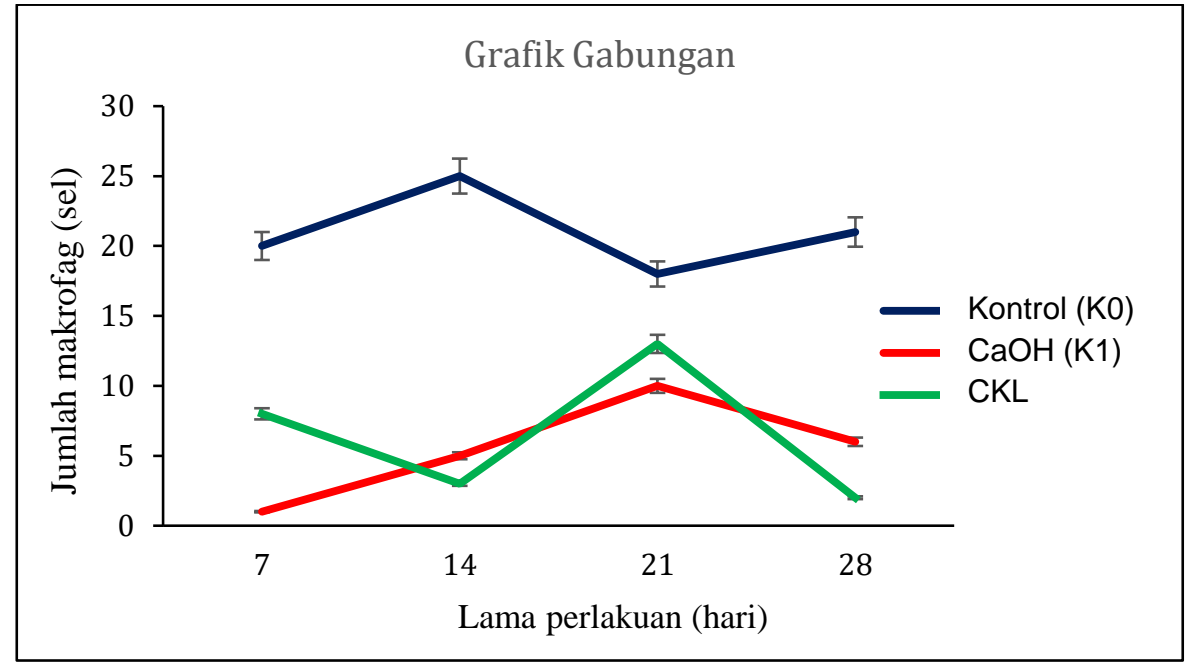

Gambar 1. Deskripsi jumlah makrofag menurut jenis dan lama perlakuan

Dari gambar 1 menunjukkan jumlah makrofag pada semua kelompok meningkat hari ke 7 sejak pembukaan atap jaringan pulpa. Kelompok CKL, jumlah sel makrofag pada lama perlakuan 7 hari menuju ke hari 21 terjadi kenaikan kemudian menurun menuju hari ke 28 Jumlah sel makrofag kelompok $\mathrm{K} 1$ kecenderungan meningkat dari hari ke 7 menuju 
pada hari ke 21 kemudian menurun dengan jumlah ekspresi makrofag masih tinggi dibanding hari ke 14.

Hasil analisis normalitas sebaran data dengan uji Kolmogorov Smirnov pada data residual standardized diperoleh sebaran normal $(p>0,05)$. Hasil uji homogenitas varian dengan uji Levene juga didapat varian data yang homogen $(p>0,05)$. Perbedaan jumlah makrofag menurut jenis dan lama perlakuan dilakukan uji two way ANOVA dengan hasil yang ditunjukkan pada Tabel 2 sebagai berikut

Tabel 2. Perbedaan rerata jumlah makrofag pada kelompok kombinasi kasein laktoferin, $\mathrm{CaOH}$, dan tanpa perlakuan dalam berbagai lama perlakuan

\begin{tabular}{lll}
\hline & F hitung & $p$-value \\
\hline Jenis perlakuan & 311,379 & 0,000 \\
Lama perlakuan & 11,034 & 0,000 \\
Jenis x lama perlakuan & 19,310 & 0,000 \\
\hline
\end{tabular}

Berdasarkan Tabel 2 diketahui bahwa jenis perlakuan, lama perlakuan, dan interaksi antara jenis dan lama perlakuan berpengaruh signifikan terhadap jumlah makrofag, yang ditunjukkan dengan perolehan nilai $p$ masing-masing sebesar 0,000 $(p<0,05)$.

Perbedaan jumlah makrofag menurut jenis dan lama perlakuan, berikutnya dianalisis lebih lanjut dengan uji post hoc LSD yang hasilnya diketahui bahwa perbedaan jumlah makrofag antara bahan $\mathrm{CKL}$ dalam berbagai lama perlakuan berbeda signifikan dengan di kelompok kontrol juga dengan kelompok K1 $(p$ $\leq 0,05)$, kecuali perbedaan jumlah makrofag antara bahan CKL dengan K1 pada lama perlakuan 14 hari $(p>0,05)$.

\section{PEMBAHASAN}

Makrofag membantu pertahanan imunitas, pengaturan imun dan perbaikan jaringan. Berdasarkan produksi sitokin dan aktivasinya, makrofag diklasifikasikan menjadi dua populasi: M1 pro-inflamasi (makrofag teraktivasi klasik) dan M2 anti-inflamasi (makrofag teraktivasi) di arah lain). Calprotectin dapat menginduksi sitokin pro-inflamasi dalam monosit dan makrofag melalui jalur NF-kB dan p38 MAPK ${ }^{13}$. Makrofag adalah sel yang berkontribusi pada pembentukan reparative dentin melalui aktivasi sel pulpa ${ }^{14}$, ketika jumlah makrofag berkurang selama perbaikan, maka berpengaruh pada pembentukan dentin reparative nya. Pengaktifan sel pulpa tersebut akan menginduksi respons antiinflamasi makrofag melalui Pensinyalan Wnt / catenin ${ }^{15}$. Meskipun, inflamasi merupakan prasyarat untuk penyembuhan dan regenerasi bila peradangan dalam jangka lama maka menyebabkan kerusakan pulpa yang lebih parah, yang dapat menghambat proses regeneratif. Inflamasi yang berlanjut dan meluas dapat terjadi pada jaringan pulpa karena karakteristik morfologis jaringan pulpa yaitu jaringan lunak yang dikelilingi jaringan keras sehingga tidak terdapat area pembengkaan ${ }^{9}$.

Berdasarkan hasil penelitian juga hasil uji analisis Anava 2 jalur diketahui bahwa jenis dan lama aplikasi bahan kaping baik pada CKL dan 
K1 berpengaruh terhadap jumlah ekspresi makrofag. Hal ini mungkin disebabkan sifat karakteristik biologi dari bahan kaping yang dapat mengindukasi respons jaringan pulpa di bawahnya. Kemampuan kompatibilitas dan sitotoksitas dari bahan kaping memengaruhi kemampuan biologis bahan untuk menghindari atau membatasi iritasi atau degenerasi jaringan pulpa ${ }^{16}$, di mana masing-masing bahan kaping memiliki pengaruh terhadap proses inflamasi dan regenerasi jaringan pulpa yang terdapat kerusakan ${ }^{17}$. Pada tabel 1 menunjukkan bahwa jumlah ekspresi makrofag pada aplikasi bahan kombinasi kasein dan laktoferin kolostrum susu sapi lebih banyak daripada kalsium hidroksida, hal ini dimungkinkan karena kemampuan bahan aktif dari kasein dan laktoferin sebagai bahan imunodulator yang menimbulkan reaksi biomolekuler bagi sel pulpa. Diketahui pulpa gigi memiliki kemampuan pertahanan terhadap kerusakan yang mendekati pulpa dengan reaksi inflamasi dan melakukan regenerasi pulpa dentin. Kemampuan tersebut meliputi interaksi sel endothelial dengan sel inflamasi, interaksi stem cell di jaringan pulpa dengan sel fibroblast pulpa serta proliferasi , migrasi dan diferensiasi sel pulpa ${ }^{18}$. Sedangkan dari tabel 1 menunjukkan pula pada kelompok kontrol (K0) yaitu kelompok yang tidak diberikan bahan perawatan kaping pulpa setelah preparasi kavitas, menunjukkan proses inflamasi dengan jumlah ekpresi makrofagnya paling banyak sejak hari ke 7 sampai hari ke 28 dibanding pemakaian bahan kaping $\mathrm{CKL}$ dan $\mathrm{K} 1$. Hal ini dimungkinkan karena kerusakan sel odontoblas di bawah pembukaan pulpa menimbulkan iritasi yang berat sehingga stimulus tersebut melebihi kapasitas penyembuhan pulpa sehingga memengaruhi proses inflamasi pada kompleks dentin-pulpa termasuk proses regenerasi jaringan pulpanya ${ }^{19}$.

Pada gambar 1 menunjukkan mekanisme keberlangsungan proses inflamsi yang berkaitan dengan proses regenerasi jaringan pulpa. Grafik tersebut menunjukkan bahwa pada hari ke 7 semua perlakuan terlihat keberadaan ekspresi sel makrofag, hal ini berarti preparasi yang mendekati pembukaan atap pulpa pada penelitian ini menimbulkan reaksi dari jaringan odontoblas di bawahnya sebagai pertahanan pertama dengan memulai proses inflamasi yaitu memproduksi sitokin pro inflamasi ${ }^{20}$. Hal ini sejalan penelitian lainnya yang menyatakan bahwa sel odontoblas akan mengaktifkan jalur NF-kB sebagai respon inflamasi bila terjadi kerusakan mendekati jaringan pulpa ${ }^{21}$.

Pada gambar 1 juga menunjukkan bahwa ada kecenderungan kenaikan jumlah makrofag pada pemakaian kombinasi kasein laktoferin ( $\mathrm{CKL}$ ) di hari ke 7 menuju hari ke 14 . Hal ini, menunjukkan bahwa pemakaian bersama 2 macam protein yang dicampur menjadi satu yaitu CKL berfungsi sebagai imunomodulator. Hal ini kemungkinan dikarenakan adanya peningkatan kemampuan dari adanya gabungan protein dari kasein dan laktoferin yang memicu ekspresi makrofag. Pengamatan hari ke 7 adalah saat berlangsungnya fase inflamasi di mana terjadi peningkatan jumlah makrofag atas terbukanya atap pulpa, sebagai respons awal host terhadap infeksi. Jumlah Makrofag sebagai respons awal terhadap infeksi mengalami perubahan sehubungan fungsinya yaitu mengenali rangsangan inflamasi, inisiasi respon inflamasi berupa produksi sitokin proinflamasi, dan pembersihan pathogen 22. Pada pengamatan hari ke 7 dari penggunaan gabungan bahan kasein dan laktoferin pada 
pulpa terbuka, jumlah ekspresi sel makrofagnya sudah tinggi hal ini dikarenakan karena sifat masing masing protein yang mendukung terjadinya proliferasi dan peningkatan terjadinya sinyal biologi ${ }^{23}$, dan yang paling menonjol pada kelompok pengamatan hari ke 21 . Hal ini berarti pada waktu pengamatan tersebut adalah jumlah makrofag mencapai puncaknya, hal ini dimungkinkan bahwa pada pengamatan hari ke 14 menuju ke 21 fungsi makrofag mencapai puncaknya yaitu selain produksi sitokin proinflamasi saat inflamasi juga melakukan fungsi untuk regenerasi jaringan. Diketahui bahwa peningkatan Wnt memengaruhi polarisasi makrofag selama perbaikan dentin di mana polarisasi makrofag M1 ke M2 merupakan faktor penting untuk meningkatkan TGF- $\beta 1$ pada perbaikan jaringan 24 .

Ekspresi makrofag pada pemakaian bahan CKL di grafik 1 cenderung lebih tinggi dari $\mathrm{CaOH}$, hal ini dimungkinkan karena kasein dan laktoferin yang memiliki pengaruh menstimulasi makrofag. Diketahui laktoferin yang mengandung Ig memicu aktivasi produksi sitokin proinflamasi langsung oleh makrofag. Laktoferin memicu polarisasi M2 melalui jalur CD14/tolllike receptor (TLR) 4 dan FcyRlla (CD32a) ${ }^{25}$. Toll-like receptor (TLR) adalah kelompok glikoprotein yang berfungsi sebagai reseptor permukaan transmembran dan terlibat dalam respons imun alami terhadap infeksi. Selanjutnya TLR memulai jalur yang memberi sinyal untuk mengaktifkan sitokin dan kemokin. Fc adalah reseptor untuk bagian Fc dari imunoglobulin (lg). FcyRlla adalah reseptor permukaan sel untuk Ig yang interaksinya memicu respons sistem kekebalan atau fisiologi antibodi kekebalan ${ }^{26}$. Demikian pula dengan kcasein, $\beta$-casein (b-CN), protein $\beta-C N$ (193-
209) yang merupakan immunomodulatory peptides. Peningkatan variable sel imun protein b-CN meningkatkan ekspresi molekul makrofag 2 24, serta kappa-kasein merupakan imunomodulator yang kuat bagi makrofag ${ }^{12}$. Aplikasi bahan kaping dengan kombinasi kasein dan laktoferin menunjukkan bahwa pada hari ke 21 jumlah ekspresi makrofag menurun, hal ini kemungkinan disebabkan karena keadaan signaling mulai mereda, di mana jumlah sitokin mulai menurun, proses inflamasi telah banyak berkurang, dan luka akan diisi oleh proliferasi jaringan

Jumlah ekspresi makrofag pada pemakaian $\mathrm{CaOH}$ (K1) lebih sedikit dari pada pemakaian $\mathrm{CKL}$, hal ini kemungkinan karena sifat alkali bahan $\mathrm{K} 1$ yang tinggi dan menimbulkan area nekrosis pada jaringan pulpa di bawah dan sekitar aplikasi bahan . Dari grafik 1 menunjukkan pula kecenderungan jumlah ekspresi $\mathrm{CaOH}$ yang melambat peningkatannya hal ini dimungkinkan adanya penundaan yang lebih lama dalam proses perbaikan, dengan area nekrotik yang luas menyebar ke jaringan pulpa. Pada kelompok $\mathrm{CaOH}$ menunjukkan beberapa sel inflamasi, peningkatan terjadi saat menuju hari ke 21, menghasilkan nekrosis jaringan yang besar. $\mathrm{Ph}$ yang tinggi pada kalsium hidroksida menyebabkan nekrosis koagulasi 27 . Pada kondisi nekrosis koagulasi aktivitas enzim dihambat sehingga bentuk area nekrotik akan bertahan beberapa minggu dan selanjutnya akan menurunkan vakuolisasi dan lebih banyak jaringan nekrotik terjadi pada $\mathrm{CaOH}{ }^{28}$. Hal ini, dapat menjelaskan mengapa pada penggunaan bahan kaping dengan $\mathrm{CaOH}$ terjadi multiple tunnel defect yang berakibat pembentukan jembatan dentin tidak maksimal . 


\section{KESIMPULAN}

Berdasarkan hasil penelitian yang telah dilakukan, dapat disimpulakn bahwa:

1. Kombinasi kasein laktoferin kolostrum susu sapi sebagai bahan perawatan kaping pulpa berpengaruh terhadap ekspresi makrofag

2. Lama aplikasi kombinasi kasein laktoferin kolostrum susu sapi sebagai bahan perawatan kaping pulpa berpengaruh terhadap ekspresi makrofag selama 7,14,21 dan 28 hari

3. Kombinasi kasein dan kolostrum laktoferin susu sapi sebagai bahan kaping dapat meningkatkan jumlah makrofag dalam proses penyembuhan pulpa gigi

\section{REFERENSI}

1. Nicholson LB. The immune system. Essays Biochem. 2016;60(3):275-301.

2. Brancato SK, Albina JE. Wound macrophages as key regulators of repair: Origin, phenotype, and function. Am J Pathol. 2011;178(1):19-25.

3. Koh T and DLA. Inflammation and wound healing: The role of the macrophage. Expert Rev Mol Med. 2013;13(e23):1-14.

4. Duque GA, Descoteaux A. Macrophage cytokines: Involvement in immunity and infectious diseases. Front Immunol. 2014;5(OCT):1-12.

5. Ginhoux F, Jung S. Monocytes and macrophages: Developmental pathways and tissue homeostasis. Nat Rev Immunol. 2014;14(6):392-404.

6. Soufli I, Toumi R, Rafa H, Touil-Boukoffa C. Overview of cytokines and nitric oxide involvement in immuno-pathogenesis of inflammatory bowel diseases. World J Gastrointest Pharmacol Ther. 2016;7(3):353.

7. Bogdan $C$, Röllinghoff $M$, Diefenbach $A$. The role of nitric oxide in innate immunity. Immunol Rev. 2000;173(1):17-26.

8. Bjørndal L, Demant S, Dabelsteen S. Depth and activity of carious lesions as indicators for the regenerative potential of dental pulp after intervention. J Endod. 2014;40(4 SUPPL.):S76-81.

9. Cooper PR, Chicca IJ, Holder MJ, Milward MR. Inflammation and Regeneration in the
Dentin-pulp Complex: Net Gain or Net Loss? J Endod. 2017;43(9):S87-94.

10. Sehgal A, Donaldson DS, Pridans $C$, Sauter KA, Hume DA, Mabbott NA. The role of CSF1R-dependent macrophages in control of the intestinal stem-cell niche. Nat Commun. 2018;9(1):1-17.

11. Siqueira JF, Lopes HP. Mechanisms of antimicrobial activity of calcium hydroxide: A critical review. Int Endod J. 1999;32(5):361-9.

12. Lalor R, O'Neill S. Bovine k-casein fragment induces hypo-responsive m2-like macrophage phenotype. Nutrients. 2019;11(7).

13. Chen $X$, Chen $W, H e ~ Y$, Zhang $Y$, Chen $C$, Zhu Z, et al. The p38 MAPK and NF-KB pathways are involved in cyclic compressive force-induced IL-6 secretion in MLO-Y4 cells. Brazilian Arch Biol Technol. 2018;61.

14. Neves VCM, Yianni V, Sharpe PT. Macrophage modulation of dental pulp stem cell activity during tertiary dentinogenesis. Sci Rep. 2020;10(1):1-9.

15. Neves VCM, Babb R, Chandrasekaran D, Sharpe PT. Promotion of natural tooth repair by small molecule GSK3 antagonists. Sci Rep. 2017;7(November 2016):1-7.

16. Modena KC da S, Casas-Apayco LC, Atta MT, Costa CA de S, Hebling J, Sipert CR, et al. Cytotoxicity and biocompatibility of direct and indirect pulp capping materials. $J$ Appl Oral Sci. 2009;17(6):544-54.

17. Giraud T, Jeanneau C, Rombouts C, Bakhtiar $\mathrm{H}$, Laurent $\mathrm{P}$, About I. Pulp capping materials modulate the balance between inflammation and regeneration. Dent Mater. 2019;35(1):24-35.

18. Rombouts C, Jeanneau C, Bakopoulou A, About I. Dental Pulp Stem Cell Recruitment Signals within Injured Dental Pulp Tissue. Dent J. 2016;4(2):8.

19. Zaky SH, Shehabeldin M, Ray H, Sfeir C. The role of inflammation modulation in dental pulp regeneration. Eur Cells Mater. 2021;41:184-93.

20. Ley K, Laudanna C, Cybulsky MI, Nourshargh S. Getting to the site of inflammation: The leukocyte adhesion cascade updated. Nat Rev Immunol. 2007;7(9):678-89.

21. Lawrence T. The nuclear factor NF-kappaB pathway in inflammation. Cold Spring Harb Perspect Biol. 2009;1(6):1-11.

22. Elsalhy $M$, Azizieh $F$, Raghupathy $R$. Cytokines as diagnostic markers of pulpal inflammation. Int Endod J. 2013;46(6):573- 
80.

23. Farges J-C, Alliot-Licht B, Renard E, Ducret M, Gaudin A, Smith A., et al. Dental Pulp Defence and Repair Mechanisms in Dental Caries. Mediators Inflamm. 2015;2015:116.

24. Sandre C, Chilmonczyk S. Nutritional Immunology A Peptide Derived from Bovine [? -Casein Modulates Functional Properties of Bone Marrow-Derived Macrophages from Germfree and Human FloraAssociated Mice 1. 2018;(August 2001):2936-42.

25. Gao $\mathrm{CH}$, Dong $\mathrm{HL}$, Tai L, Gao XM. Lactoferrin-containing immunocomplexes drive the conversion of human macrophages from M2-into M1-like phenotype. Front Immunol. 2018;9(JAN):1-
11.

26. Anania JC, Chenoweth AM, Wines BD, MarkHogarth $\mathrm{P}$. The human FcyRII (CD32) family of leukocyte FCR in health and disease. Front Immunol. 2019;10(MAR):117.

27. Kunarti S. Pulp tissue vacuolization and necrosis after direct pulp capping with calcium hydroxide and transforming growth factor- $\beta 1$. Dent J (Majalah Kedokt Gigi). 2008;41(1):35.

28. Pallotta RC, Machado ME de L, Reis NS dos, Martins GHR, Nabeshima CK. Tissue inflammatory response to implantation of calcium hydroxide and iodoform in the back of rats. Rev Odonto Ciência. 2010;25(1):59-64. 